\title{
A Newborn with Bilateral Breast Enlargement: Neonatal Mastauxe
} Iki Taraflı Meme Büyümesi olan Bir Yenidoğan: Neonatal Mastauxe

\author{
(1) Selin Sevinç¹, (1) Eda Almus², (1) Emel Okulu³, (1) Elif Özsu4, (1) Ömer Erdeve33, (1) Begüm Atasay3, (1) Saadet Arsan³ \\ ${ }^{1}$ Ankara University Faculty of Medicine, Department of Pediatrics, Ankara, Turkey \\ ${ }^{2}$ Ankara University Faculty of Medicine, Department of Radiology, Division of Pediatric Radiology, Ankara, Turkey \\ ${ }^{3}$ Ankara University Faculty of Medicine, Department of Pediatrics, Division of Neonatology, Ankara, Turkey \\ ${ }^{4}$ Ankara University Faculty of Medicine, Department of Pediatrics, Division of Pediatric Endocrinology, Ankara, Turkey
}

\section{Abstract}

Neonatal breast enlargement is a common condition as a normal response to postnatally falling maternal hormones. It can be seen in the first weeks and usually progresses during the first 2 months of life. We herein report a male newborn who was admitted with bilateral breast enlargement, diagnosed as neonatal "giant" mastauxe, and followed up without treatment. "Neonatal mastauxe" is the term used for physiological breast enlargement. It is important to differentiate neonatal mastauxe from mastitis or abscess. The parents should be informed about that it resolves without treatment over a few weeks of period, and they should be warned to avoid squeezing the breast. The most adequate approach is to observe the regression of breast swelling.

Key Words: Newborn, Breast Enlargement, Mastauxe

\section{Özet}

Yenidoğanda meme büyümesi, doğum sonrası düzeyi düşen maternal hormonlara normal bir yanıt olarak görülen yaygın bir durumdur. Doğumdan sonraki ilk haftalarda görülebilmekte ve genellikle 2 ay civarında gerilemektedir. Burada, iki taraflı meme büyümesi ile başvurup "dev" neonatal mastauxe tanısı konulan ve tedavisiz takip edilen bir erkek yenidoğan bebek sunulmaktadır. "Neonatal mastauxe" fizyolojik meme büyümesini ifade etmekte olup mastit veya apseden ayırt edilmesi önemlidir. Aileler memedeki şişliğin haftalar içinde tedavisiz gerilediği yönünde bilgilendirilmeli, memeyi ovmamaları ve sıkmamaları konusunda uyarılmalıdır. En uygun yaklaşım, memedeki şişliğin gerilemesini takip etmektir.

Anahtar Kelimeler: Yenidoğan, Meme Büyümesi, Mastauxe

\section{Introduction}

Neonatal breast enlargement is a common condition that can be seen in early weeks of life. It has been reported among $65-90 \%$ of infants in neonatal period $(1,2)$. This enlargement is due to decreased levels of maternal estrogen at the end of pregnancy which trigger the release of prolactin from the pituitary gland of the newborn (3).

Neonatal galactorrhea can accompany to breast enlargement in some cases (1). The enlarged breast may discharge liquid which is popularly known as "witch's milk" and shown to mimic the maternal milk composition. Although this is usually a benign physical feature that resolves spontaneously over time, antibiotic treatment is required if mastitis or abscess formation occurs $(1,4,5)$.

We herein report a male newborn who admitted to hospital with bilateral breast enlargement and followed up without treatment.

\section{Case Report}

A 19-day-old male newborn was admitted with bilateral breast enlargement. He was born at 37 weeks' gestation by vaginal delivery after an uncomplicated pregnancy with a birth weight of $3440 \mathrm{~g}, 8$ and 10 APGAR scores at 1-minute 
and 5-minutes, respectively. He was followed up with neonatal jaundice which was not needed phototherapy and inadequate weight gain in first two weeks of his life. The parents noted that the breasts were slightly swollen at birth and continued to get larger during the subsequent days. They also stated that they squeezed and rubbed the breasts to reduce the size in last three days before admission.

The examination of the chest revealed enlarged bilateral breast tissue more than $3 \mathrm{~cm}$ with no evidence of inflammation, fluctuation, tenderness or discharge (Figure 1). Laboratory evaluation revealed a normal white blood cell (WBC) count $\left[W B C=12400 / \mathrm{mm}^{3}\right.$ (range: $\left.\left.5000-20000 / \mathrm{mm}^{3}\right)\right]$, and C-reactive protein (CRP) level [CRP=1.2 mg/L (range: $0.0-5.0 \mathrm{mg} / \mathrm{L}$ )]. The gray-scale ultrasound imaging showed well-defined oval masses with a size of $31 \times 16 \mathrm{~mm}$ and $30 \times 10 \mathrm{~mm}$ at left and right breast, respectively including tiny anechoic cystic images without abscess collection (Figure 2). As the infection parameters were negative and the ultrasound imaging revealed "neonatal giant mastauxe", the antibiotic treatment was not started. The hormonal evaluation showed elevated prolactin level (78.71 ng/ $\mathrm{mL}$; reference range, 2.64-13.13 ng/mL) with normal levels of follicle-stimulating hormone, luteinizing hormone and estradiol.

He was discharged to continue to follow up. Two weeks later, the breast tissue of the infant was seen to be smaller without any infectious appearance.

\section{Discussion}

Neonatal breast enlargement is a normal response to postnatally falling levels of maternal estrogen which is thought

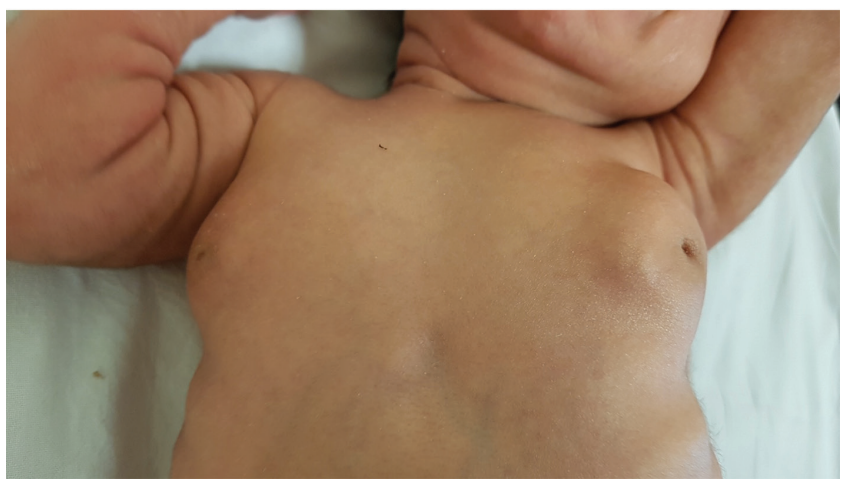

Figure 1: Male newborn with bilateral breast enlargement
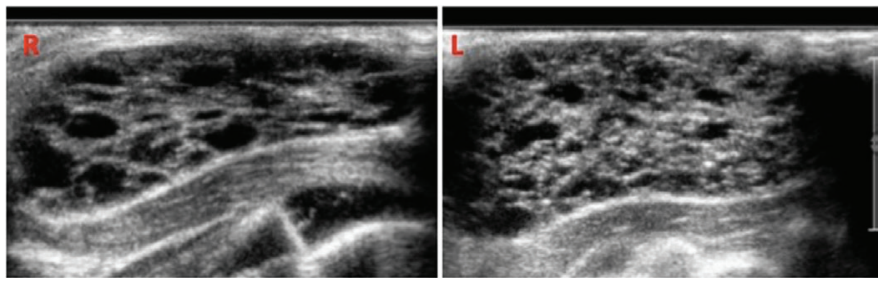

Figure 2: Ultrasonographic images of right and left breast showing increased glandular tissue containing cystic and tubular anechoic areas to induce the releasing of prolactin from newborn's pituitary gland and usually progress during the first 2-months of life. Although it is considered that hypersensitivity of the breast tissue to estrogen and/or prolactin is the main factor for this condition, the reason for variability in the response to hormones in newborns remains unclear. Bilateral involvement is rare besides there is no side predilection, and it is independent of the sex of the baby $(1,3)$.

"Mastauxe" is a word which is a combination of two Greek words of "mastos" which means breast and "auxein" which means increase in size. "Neonatal mastauxe" is used to distinguish the physiological from pathological breast enlargement. The Table 1 shows the suggestions of Athena for terminology (3).

Neonatal breast enlargement is a common condition and is seen in 65-90\% of infants in neonatal period. It usually occurs in early weeks of life, and resolves within a few weeks $(4,6)$. Suthar and Aggarwal (7) reported a 2-week old female baby presented with bilateral breast enlargement with redness and non-bloody, milk-like discharge who started on parenteral antibiotic due to undistinguishable from neonatal mastitis until sonographic imaging revealed actually breast mass without signs of inflammation. A girl baby was reported by Amer and Fischer (2) who admitted with bilateral breast enlargement at the end of her first week. Our case was a male infant who admitted with bilateral breast enlargement without milk secretion at the end of third week of his life and he had high prolactin level as expected.

It is important to differentiate neonatal mastauxe from mastitis or abscess that require antibiotic therapy or further

\begin{tabular}{ll}
$\begin{array}{l}\text { Table 1: The terminologies suggested for neonatal breast } \\
\text { enlargement (3) }\end{array}$ & $\begin{array}{l}\text { Physiological breast enlargement-breast } \\
\text { bud diameter } \leq 3 \mathrm{~cm}\end{array}$ \\
Neonatal mastauxe & $\begin{array}{l}\text { Exaggerated form of neonatal mastauxe- } \\
\text { breast bud diameter }>3 \mathrm{~cm}\end{array}$ \\
Giant mastauxe & $\begin{array}{l}\text { Macroscopic (cystic) accumulation of milk } \\
\text { (>0.5 } \mathrm{mL} \text { ) within the lactiferous channels } \\
\text { of newborn }\end{array}$ \\
Neonatal galactocele & $\begin{array}{l}\text { Excessive (>1.5 mL/day) and/or prolonged } \\
\text { (>12 weeks) milk secretion in newborn }\end{array}$ \\
Neonatal galactorrhea & $\begin{array}{l}\text { Scanty amount of milky secretion from } \\
\text { neonatal breast }\end{array}$ \\
Neonatal lactation & $\begin{array}{l}\text { Male breast development beyond neonatal } \\
\text { period involving mammary fat and glands }\end{array}$ \\
Gynecomastia & $\begin{array}{l}\text { Female breast development beyond } \\
\text { neonatal period involving mammary fat } \\
\text { and glands } \\
\text { Inflammation of neonatal breast due to } \\
\text { superadded infection }\end{array}$ \\
Premature thelarche & $\begin{array}{l}\text { Neonatal mastitis with macroscopic } \\
\text { accumulation of pus within or adjacent to } \\
\text { the breast }\end{array}$ \\
\hline Neonatal mastitis & $\begin{array}{l}\text { Neonatal } \\
\text { breast abscess }\end{array}$
\end{tabular}


approaches like needle aspiration. It has been reported that approximately one half of neonatal mastauxe progresses to mastitis, and one half of neonatal mastitis progresses to breast abscess. The most common isolated agent that reported in breast abscess is Staphylococcus aureus. A detailed physical examination can show the signs of inflammation as hyperemia, heat, tenderness or discharge. Ultrasonography is an important imaging modality to distinguish the mastauxe and mastitis/ breast abscess $(3,8)$. In our case, antibiotic treatment was not started because infection was excluded by laboratory evaluation and sonographic findings revealed "neonatal giant mastauxe". Long term follow-up is recommended in infants with neonatal breast enlargement due estrogen hypersensitivity hypothesis which make breast more vulnerable for malignant changes in adulthood (3).

Management of neonatal breast enlargement is only observation and follow its regression spontaneously. The main problems for these cases are expression and squeezing of breast tissue especially done by parents. Both may lead to stimulate further growth of the breast as well as prolong the milk secretion, and predispose to complications such as mastitis and abcess. Therefore, these should be highly discouraged $(3,7)$.

In conclusion; in newborns, breast enlargement is a benign finding that requires simple observation and parental reassurance. It is important to differentiate mastauxe from mastitis or abscess both with physical examination and ultrasonographic imaging. Parents should be informed that breast enlargement usually resolves without treatment over a period of a few weeks, and should be warned not to squeeze the breast. These infants should be followed up to observe the regression of the breast swelling.

\section{Ethics}

Informed Consent: The informed consent was obtained from patient's parent.
Peer-review: Externally peer-reviewed.

\section{Author Contributions}

Concept and design: S.S., E.A., E.O., Data collection or processing: S.S., E.A., E.Ö, Analysis or Interpretation: S.S., E.O., O.E, B.A., S.A, Drafted the initial manuscript: S.S., E.O., Critically reviewed and revised the final manuscript: Ö.E., S.A., Approval for the final manuscript: S.S., E.A., E.O., E.Ö, Ö.E., B.A., S.A.

Conflict of Interest: The authors declared no potential conflicts of interest with respect to the research, authorship, and/or publication of this article.

Financial Disclosure: The authors received no financial support for the research, authorship, and/or publication of this article.

\section{References}

1. Cameselle-Teijeiro JF, Mallo R, Otero M, et al. Alterations in the development of the breast newborn: Giant Mastauxe (Exaggerated form of Neonatal Mastauxe). Open J Clin Med Case Rep. 2016;2:1197.

2. Amer $A$, Fischer $H$. Neonatal breast enlargement. N Engl J Med. 2009;360:1445.

3. Raveenthiran V. Neonatal Mastauxe (Breast Enlargement of the Newborn). J Neonatal Surg. 2013;2:31.

4. Donaire A, Guillen J, Rajegowda B. Neonatal Breast Hypertrophy: Revisited. Pediatr Ther. 2016;6:297.

5. Yap PL, Mirtle $C L$, Harvie $A$, et al. Milk protein concentrations in neonatal milk (witch's milk). Clin Exp Immunol. 1980;39:695-697.

6. Lawrence RA, Lawrence RH. Breastfeeding: A Guide for the Medical Professional. In: Lawrence RA, Lawrence RH, editors. Anatomy of the Breast. 8th ed. Philadelphia: Mosby; 2006. p. 34-55. https://iums.ac.ir/files/vch/ files/laranc.pdf

7. Suthar B, Aggarwal K. A rare case of neonatal mastauxe: case report. Indian J Radiol Imaging. 2019;29:89-93.

8. Ruwaili NA, Scolnik D. Neonatal mastitis-controversies in management. $J$ Clin Neonatol. 2012;1:207-210. 